\title{
Mercury Contamination in Surface Sediments and Sediment Cores of the Mersey Estuary, UK
}

\author{
C.H. Vane*, D.G. Jones and T.R. Lister \\ British Geological Survey, Kingsley Dunham Centre, Keyworth, Nottingham, \\ NG12 5GG, United Kingdom
}

Mercury $(\mathrm{Hg})$ is one of the most important heavy metals in estuarine and coastal sediments. This is due to its toxic effect on marine invertebrates and tendency for the methyl-Hg to bio-accumulate up trophic levels, where it can enter humans via the ingestion of fish and shellfish (Boening, 2000; Bryan and Langston, 1992; Haitzer et al., 2003; Long et al., 1995). The Mersey estuary (NW England, UK) has a highly industrialised and urbanised drainage basin of approximately $5000 \mathrm{~km}^{2}$. Elevated $\mathrm{Hg}$ concentrations ( $>2 \mathrm{mg} / \mathrm{kg}$ ) in sediments from the Mersey estuary can be attributed in part to the high density of chemical factories in the Widnes-Runcorn area (Fig. 1). In particular, the alkali, bleaching and detergents industries developed in this area in the mid- $19^{\text {th }}$ century used the Castner-Kellner process for large-scale sodium hydroxide and bleach production. This process required a flowing liquid mercury cathode in an electrolytic reaction cell. Losses and discharges from such plants, plus releases from other industries and domestic coal-burning, will have released many tonnes of $\mathrm{Hg}$ to the estuary over several decades. In addition to their anthropogenic metal burden, Mersey estuary sediments are also contaminated with persistent organic pollutants (POPs) sourced from the dockyards, shipping, chemical works, oil refineries and 
sewage works situated in close proximity to the Mersey, its tributaries and Manchester Ship Canal (Harino et al., 2003; Leah et al., 1997; Osborne et al., 1997; Thomas et al., 2002; Vane et al., 2007).

The extent of Hg contamination in surface sediments along three transects within the Mid Mersey was examined in 1983 (Craig and Moreton, 1986). Average Hg concentrations of $1.47 \mathrm{mg} / \mathrm{kg}(\mathrm{n}=21)$, with values ranging from $<0.05$ to $4.01 \mathrm{mg} / \mathrm{kg}$ and methyl-Hg concentrations ranging from $<0.0005$ to $0.024 \mathrm{mg} / \mathrm{kg}$, were reported. Monitoring of metal contamination in surface sediments from 1974 to 1998 revealed that metal concentrations including Hg were strongly correlated to organic matter and sediment particle size, resulting in distribution patterns which reflected sediment characteristics and dynamics (diffuse pollution) rather than the position of point input sources (Harland et al., 2001; NRA, 1995). Although a general decline in metal concentrations since its peak in the 1960's was observed, in line with reducing inputs, remobilisation of previously consolidated salt-marsh sediments was considered responsible for significant perturbations in the overall reduction trend. However, mass balance calculations have also shown that from 1990 to 1997 the Hg input into the Mersey decreased from 3100 to $300 \mathrm{~kg} / \mathrm{year}$, respectively (Harland et al., 2001).

The heavy metal contaminant history of the Mersey has also been recorded in $1 \mathrm{~m}$ cores of salt-marsh sediments from Widnes Warth and Ince Banks (Fox et al., 1999). Depth profiles of Hg, DDT, ${ }^{137} \mathrm{Cs}$ and ${ }^{239,}{ }^{240} \mathrm{Pu}$ showed that the Widnes Warth core covered a 120 year time span, whilst that from Ince Bank represented a little over 50 years of sedimentation (Fox et al., 1999). The core at Widnes Warth showed a marked increase in Hg concentrations from pre-industrial (1880) concentrations of $\sim 0.2$ to 4 $\mathrm{mg} / \mathrm{kg}$ in 1920 and about $5 \mathrm{mg} / \mathrm{kg}$ in the 1960’s. 
The objectives of the current study were to: (i) determine the distribution of $\mathrm{Hg}$ contamination near to the sediment surface within the outer, middle and inner portions of estuary; (ii) provide a vertical distribution of Hg contamination using shallow sediment cores in order to examine historic pollution trends and, (iii) evaluate Mersey Hg concentrations using published marine and estuarine sediment quality guidelines.

Sampling of the estuary of the River Mersey was carried out over a period of 30 months, with initial orientation samples collected in May 2000 and the final drill cores from Widnes Warth collected in November 2002. Four different methods of sampling were used during the field campaign, namely; manual corer, Marlow corer, Mackereth corer and Day grab. Sampling sites in the middle estuary were accessed by the Environment Agency hovercraft 'Sea-Spray’, using pre-determined GPS co-ordinates to accurately locate each position. Eight shallow cores were collected by manually driving plastic tubes, fitted with a stainless steel basket core catcher at the base, into the exposed sediment. This method recovered cores from 0.75 to $1.25 \mathrm{~m}$ in length. At one location (M232) in the outer estuary it was possible to collect cores using a Mackereth piston corer. The corer was deployed from the Environment Agency vessel 'Sea Jet'. Using compressed air, a plastic core tube was forced into the submerged sediment, enabling cores of up to $1 \mathrm{~m}$ to be recovered. A mechanically powered 'Marlow' corer was transported by barge, via the Manchester Ship Canal, and unloaded onto the salt marsh at Ince Bank. Marlow cores were recovered from four locations (IB6, IB7, IB8 \& WW1) ranging from 1.5 to $5.5 \mathrm{~m}$ in length. In the outer estuary, the Environment Agency vessel ‘Coastal Guardian’ was used to collect samples from the submerged estuary bed with a Day grab. Pre-determined GPS coordinates were used to accurately locate each site. The locations for the 14 sediment cores are presented in Fig 1. 
After collection, sediment cores and grabs were stored frozen in the dark to avoid post collection chemical change and then transported to the laboratory. Core samples were defrosted and sampled at $10 \mathrm{~cm}$ intervals using a plastic spatula. The resultant samples were freeze-dried, sieved to pass a $2 \mathrm{~mm}$ brass mesh then carefully ground to a fine powder in an agate ball mill. Grab samples were homogenised and prepared in an identical manner to the core samples. A total of 203 sediment samples were subsequently analysed for $\mathrm{Hg}$ content. For each digest, $0.5 \mathrm{~g}$ sediment was treated with $5 \mathrm{ml}$ deionised water and $5 \mathrm{ml}$ of Aqua Regia for $15 \mathrm{~h}$, and then heated at boiling point for $2 \mathrm{~h}$. Once cooled, $50 \mathrm{ml}$ of deionised water was added and shaken. After settling, a $5 \mathrm{ml}$ aliquot was transferred and diluted with $18 \mathrm{M} \Omega$ quality water to give a 2\% acid solution. The samples were analysed using PSA, atomic fluorescence spectrometer system comprised of a XYZ Autosampler and a Millennium Merlin spectrometer operated with an Ar flow rate of 30-50 psi and fluorescence measured at $253.7 \mathrm{~nm}$. The limit of quantification was $0.002 \mathrm{mg} / \mathrm{kg}$. Quality control was accomplished by analysing BEST-1, a low-level Hg reference marine sediment (laboratory of the government chemists), and PACS-1, a high-level Hg reference material. A total of nine QC analyses were conducted at regular intervals throughout the analysis of the samples (Table 1).

Loss-on-Ignition (LoI), a proxy for total organic carbon (TOC), was determined by heating known weights of sample (dried at $105^{\circ} \mathrm{C}$ overnight) to $450^{\circ} \mathrm{C}$ in a muffle furnace for a minimum of 4 hours. After cooling, the samples were re-weighed and the percentage loss in weight (LoI) calculated. Quality control was achieved through the use of two in-house QC standards: LLC (low level control) and S3B (high level control) with LoIs of $3.5 \%$ and $12.5 \%$, respectively. These were run alternately in each batch of 40 samples. 
Gamma-emitting radionuclides (principally ${ }^{137} \mathrm{Cs}$ and ${ }^{40} \mathrm{~K}$ ) were determined on intact sediment cores in their plastic liners by gamma spectrometry, using an automated core logger developed at BGS; this is a rapid, non-destructive screening method. The cores were moved in $2 \mathrm{~cm}$ increments past a 76 x $76 \mathrm{~mm} \mathrm{NaI(Tl)} \mathrm{gamma}$ detector surrounded by $10 \mathrm{~cm}$ of low background $\mathrm{Pb}$ shield. A 1 hour count was made at each step with a full gamma spectrum collected on a Canberra Unispec MCA. Analysis of the spectra was made using Canberra Genie 2000 software with efficiency models created using ISOCS (Venkataraman et al., 1999, 2005). The method should be regarded here as semi-quantitative, although the patterns of radionuclide concentration with depth have been verified by analysis of depth slices from cores using conventional low background laboratory gamma spectrometry with a HPGe detector.

The average Hg concentration of all Mersey sediment core and surface grab samples was $2.03 \mathrm{mg} / \mathrm{kg}(\mathrm{n}=203)$ and the average for sediments from $10-50 \mathrm{~cm}$ was $3.16 \mathrm{mg} / \mathrm{kg}$. In contrast, lower average $\mathrm{Hg}$ values of $0.84 \mathrm{mg} / \mathrm{kg}$ were observed at the surface from core tops and grab samples $(0-10 \mathrm{~cm})$. The highest $\mathrm{Hg}$ concentrations at surface were observed at Ince Banks (5.13 mg/kg) and at a site close to Hale (Fig. 2). A reasonably strong correlation exists between $\mathrm{Hg}$ and $\mathrm{LoI}\left(\mathrm{R}^{2} 0.73, \mathrm{P}=<0.05\right)$, suggesting that the TOC is one of the controlling influences on Hg sorption (Fig. 3). This is expected given that Hg (II) (mercuric mercury) is known to form stable complexes with sulphur functional groups, which are present on the surfaces of particulate humic substances and adsorb to mineral colloids (Haitzer et al., 2003). In contrast, sediments from cores M232, M28 and M64 do not display a linear relationship between TOC and Hg, which indicates that other factors (e.g., grain size, 
bacteria, mineral colloids, and DOC) are also important in fixing Hg in the environment (Bengtsson and Picado, 2008).

Overall, surface sediments collected from the middle and inner Mersey estuary exhibited higher Hg concentrations compared to the outer estuary (Fig. 2). The Hg distribution pattern can be explained in part by the deposition of fine grained muds along the margins of the upper estuary and the prevalence of fine and medium grained sands, as well as gravelly sands, towards the outer estuary.

The spatial distribution of Hg in surface sediments and benthic organisms from the Mersey has been previously examined in the 1980's and compared with the estuaries of SW England (Langston, 1986). Mersey sediments were enriched in Hg compared to their SW counterparts, with the highest concentrations of 6.04 and 6.02 mg/kg observed at Stanlow (Ellesmere Port) and Widnes. The higher Hg concentrations were explained in part by the possible discharge of Hg wastes from chloro-alkali plants at Runcorn into the Manchester Ship Canal and periodic release of waters and sediments via Weaver Sluices and Eastham Locks (Langston, 1986). In the current study, sediments collected from Weaver Sluices and close to Eastham Locks gave $\mathrm{Hg}$ concentrations of $\sim 3 \mathrm{mg} / \mathrm{kg}$ which suggest a possible decline in sediment hosted Hg and waste discharges into the Manchester ship canal since the early 1980’s. These observations support the general notion that discharge and sedimentary accumulation of $\mathrm{Hg}$ in the Mersey has declined in the $21^{\text {st }} \mathrm{C}$ as compared to that occurring in the 1950’s to 1990’s (Fox et al., 1999; Harland et al., 2000; Langston, 1986).

The general progressive decrease in surface sediment Hg content from middle to outer estuary (Fig. 2) may also be attributable to increasing distance from sources of Hg discharge, such as points of exit/entry to the Manchester ship canal or possibly 
dilution of Mersey sediments with uncontaminated material from the Irish Sea. Changes in the particle size of sediments may also be a factor since previous studies have shown a net sediment transport in an E and SE direction toward the Mersey (Camacho-Ibar et al., 1992). Their examination of surface grab samples collected in Liverpool Bay in $1988(\mathrm{n}=70)$ gave mean $\mathrm{Hg}$ values of $0.56 \mathrm{mg} / \mathrm{kg}$ for the fine sediment fraction $(<90 \mu \mathrm{m})$ and $0.03 \mathrm{mg} / \mathrm{kg}$ for the coarse size fraction $(90-500 \mu \mathrm{m})$ confirming that sediments from outside the estuary had lower Hg concentrations than those from the estuary.

Thus sediments transported from Liverpool Bay into the outer Mersey could dilute Hg values via sediment mixing processes. Significant mixing of surface sediments in the outer estuary is not unexpected given that the Mersey estuary is macrotidal, with a maximum tidal range in excess of up to $10.4 \mathrm{~m}$ and spring tidal velocities reported of 2.26 (flood) and $2.16 \mathrm{~ms}^{-1}$ (ebb) for Bootle Docks (Fig 1). Two further factors may influence transport of sediments and associated contaminants in the Mersey, namely the unusual banana-shape of the estuary and the restricted water circulation within the middle and inner estuary caused by the constriction known as the "narrows" at Otterspool to Egremont (Fig 1). This notion is supported by relatively rapid flushing times from Widnes to Hale of 2 days within the inner estuary as compared to flushing times of 32 days for Warrington to Rock Lighthouse (NRA, 1995).

The Hg concentration and LoI profiles of ten near surface sediment cores from the Mersey estuary are presented in Fig. 4. The Hg concentration profile for M232, situated on the seaward side of Bootle Docks in Liverpool, varied from 1.42 to 0.83 mg/kg but did not show any clear changes in Hg values with depth. A similar nonsystematic variation in $\mathrm{Hg}$ values from 1.93 to $2.61 \mathrm{mg} / \mathrm{kg}$ was also observed for the 
entire 1.6 m length of core M290 (Fig. 4). These Hg profiles could be due to a combination of Hg intra-core mobility (e.g. physical sediment mixing, bioturbation).

In the UK, releases of the radionuclide ${ }^{137}$ Cs into the marine environment started from the Sellafield nuclear reprocessing plant in approximately 1952 (Kershaw et al., 1992). Discharges from this plant, as well as atmospheric input from weapons testing, can yield peaks in ${ }^{137} \mathrm{Cs}$ activity corresponding to about 1958, 1963 and the late 1970’s respectively (Lee and Cundy, 2001), with the possible addition of input from the Chernobyl accident in 1986. Of these, the peak of Sellafield discharges in the late 1970s is likely to the most significant event in intertidal sediments bordering the Irish Sea, but a significant lag time between discharge and its appearance in the sediments has been observed (Mackenzie et al., 1994). The profiles of ${ }^{137} \mathrm{Cs}$ down cores can give useful information for dating and estimating sedimentation rates, provided that consideration is given to sediment type and mixing, erosion and downward diffusion of ${ }^{137} \mathrm{Cs}$, which can be complex in an estuarine system (Clifton and Hamilton, 1982; Hamilton and Clarke, 1984; Kershaw et al., 1992). Cs is generally strongly sorbed to sediment or soil particles (Ritchie and McHenry, 1990) but in this current study, the presence of ${ }^{137}$ Cs throughout the entire core length (0-1.50 m; Fig. 5) suggests that the base of the core was younger than 1952 and/or there has been downward mixing of ${ }^{137} \mathrm{Cs}$ to that depth. The absence of any significant discrete peaks in the M290 ${ }^{137} \mathrm{Cs}$ depth profile, as for the Hg profile, supports strong sedimentary mixing by natural physical processes (e.g. waves, strong tidal currents or lateral migration of tidal channels in the estuary), through human activities such as dredging, by bioturbation or through downward migration of ${ }^{137} \mathrm{Cs}$. Given the strong tidal currents and channel migration processes operating in a macrotidal estuary like the Mersey, physical mixing of sediments is probably the dominant mechanism. The gradual increase in 
${ }^{137} \mathrm{Cs}$ downcore appears to mirror a similar increase in $\mathrm{K}$ and may therefore reflect a slight overall fining of the sediment with depth.

Cores M28, M248 and M275 revealed minor $\mathrm{Hg}$ values of about $0.5 \mathrm{mg} / \mathrm{kg}$ at the base (1.0-0.7m) followed by a rapid rise to reach maximum Hg concentrations of 2.52 $\mathrm{mg} / \mathrm{kg}$ at $0.45 \mathrm{~m}, 4.66 \mathrm{mg} / \mathrm{kg}$ at $0.45 \mathrm{~m}$ and $2.27 \mathrm{mg} / \mathrm{kg}$ at $0.65 \mathrm{~m}$, respectively (Fig. 4). A decline in Hg concentrations occurred to give concentrations of $1.42 \mathrm{mg} / \mathrm{kg}$ (M28), $1.30 \mathrm{mg} / \mathrm{kg}$ (M248) and $0.77 \mathrm{mg} / \mathrm{kg}$ (M275) at surface (Fig. 4). Similarly, core profiles for M245 and M64 showed a regular increase in Hg concentrations at depth and a decline in Hg concentrations from approximately $0.45 \mathrm{~m}$ and $0.25 \mathrm{~m}$ to surface respectively. In contrast, Hg concentrations in core M287 increased from $2.78 \mathrm{mg} / \mathrm{kg}$ at $1.45 \mathrm{~m}$ to $4.06 \mathrm{mg} / \mathrm{kg}$ at $0.8 \mathrm{~m}$ and then steadily decreased to give $1.79 \mathrm{mg} / \mathrm{kg}$ at the sediment surface. One possible explanation for the absence of low values at the base of the cores is that the sedimentation rate at M245, M64, M287 was higher than that at M28, M248, M275 enabling Hg accumulation to greater depth.

The ${ }^{137} \mathrm{Cs}$ and Hg profiles for M286 and M287, from the same site, are similar, with concentrations increasing from surface to about $0.8 \mathrm{~m}$ depth and then following a generally declining trend, with fluctuations to the basal depth (Figs $4 \& 5$ ). The ${ }^{137} \mathrm{Cs}$ profiles are consistent with a peak in mid-core, probably related to peak Sellafield discharges in the late 1970s, which has been broadened significantly by mixing (Mackenzie and Scott, 1982). If downward movement of ${ }^{137}$ Cs through the sediments is assumed not to have occurred then the base of the core is post-1952, implying net sedimentation rates of around $3 \mathrm{~cm}$ per year.

Fox et al. (1999) examined two $1 \mathrm{~m}$ depth sediment cores from Widnes and Ince Banks marshes for ${ }^{137} \mathrm{Cs}$ and $\mathrm{Hg}$, as well as $\mathrm{As}, \mathrm{Cr}, \mathrm{Cu}, \mathrm{Pb}$ and $\mathrm{Zn}$. A combination of organic and inorganic geochemical markers linked to industrial/historical events, 
including the presence or absence of the pesticide DDT, suggested that the observed fall in $\mathrm{Hg}$ values at the near surface (0 to $\sim 15 \mathrm{~cm}$ ) was attributable to the discontinuation of manufacturing processes and more stringent controls on the release of effluent from the late-1970s onwards. In the current study, M245, M28, M248, M287, M64, M274 and M275 Hg concentrations also decreased near surface, as compared to mid-core $\mathrm{Hg}$ maxima, confirming that $\mathrm{Hg}$ concentrations appear to have recently diminished. However, the concentration profile for M101 revealed an increase from low values of $0.03 \mathrm{mg} / \mathrm{kg}$ at $0.75 \mathrm{~m}$ up to $4.89 \mathrm{mg} / \mathrm{kg}$ at $0.35 \mathrm{~cm}$ before a slight decline and levelling off to $4.18 \mathrm{mg} / \mathrm{kg}$ at the surface, which suggested that in certain locations within the Mersey, Hg concentrations have not declined appreciably. This could be due to either re-deposition of much older contaminated material from, for example, Ince Marsh, which is reported to be actively eroding, or could be due to the erosion of surface sediments with lower Hg content from this site (NRA, 1995). Alternatively, the high concentrations at surface and greater depths could be caused by local point sources, but this seems less likely given that no upstream or downstream Hg gradient was observed in adjacent cores on the north bank and that the site is relatively rural by comparison to other portions of the estuary. Overall, the estuarine sediment cores from the middle Mersey were most contaminated in $\mathrm{Hg}$ at a depth of 40-60cm from surface, and therefore this $\mathrm{Hg}$ is not easily available to surface dwelling organisms (Fig. 4). Correlation between LoI and Hg content was evident $\left(\mathrm{R}^{2}\right.$ $=0.686$ ) for the salt marsh cores IB6, IB7 and IB8, which suggested that some of the variability in Hg content could be accounted for by the changing TOC content of the Mersey sediments (Fig. 4). Previous studies of surface sediment contamination in subtropical mangroves of China and back barrier salt marsh sediments of New Jersey, 
USA have also reported that Hg and TOC contents are correlated (Vane et al., 2008, 2009).

Salt marsh cores from Ince Banks (IB6, IB7, IB8) showed low Hg concentrations in the range of $0.02-2.2 \mathrm{mg} / \mathrm{kg}$ up to and including depths of $3.20 \mathrm{~m}$ (IB 6), $1.35 \mathrm{~m}$ (IB7), $2.64 \mathrm{~m}$ and $1.08 \mathrm{~m}$ (IB8) (Fig. 6). A gradual increase in Hg concentrations then occurred in all three cores reaching maximum $\mathrm{Hg}$ values of $6.02 \mathrm{mg} / \mathrm{kg}$ at $0.75 \mathrm{~m}$, $6.23 \mathrm{mg} / \mathrm{kg}$ at $0.15 \mathrm{~m}$ and $5.71 \mathrm{mg} / \mathrm{kg}$ at $0.25 \mathrm{~m}$ depth for IB6 and IB8, respectively. Similarly, low $\mathrm{Hg}$ values in the range of 0.01 to 0.14 were observed at the base of core WW1 (2.21-1.28 m) prior to an increase to $0.99 \mathrm{mg} / \mathrm{kg}$ at $0.71 \mathrm{~m}$ and maximal concentrations of $5.24 \mathrm{mg} / \mathrm{kg}$ at $0.24 \mathrm{~m}$ depth. A decrease in Hg concentrations then occurred at or close to the sediment surface of IB6, IB7, IB8 and WW1. The decline in Hg concentrations in the innermost levels of each salt marsh core (IB6, IB7, IB8 \& WW1) cannot be attributed to a decline in TOC content since the LoI values continue to increase in the innermost intervals (Fig. 6). Therefore, it is most likely that the decrease in $\mathrm{Hg}$ concentrations signifies a recent decline in Hg usage and discharge of industrial effluent into the Mersey catchment, and it may in fact be greater than first apparent due to higher TOC content in the core (Harland et al., 2001).

The ecological effect of $\mathrm{Hg}$ contamination in sediments can be estimated by comparison to consensus-based effects range median (ERM) limit of $0.17 \mathrm{mg} / \mathrm{kg}$ for marine and estuarine ecosystems, which defines the approximate concentration frequently associated with adverse effects to selected sensitive biota (42 \%) (Long et al., 1995). Another approach for estimating the effects on organisms is the probable effect concentrations (PEC) of $1.06 \mathrm{mg} / \mathrm{kg}$ for freshwater ecosystems (Long et al., 1995; MacDonald et al., 2000). Using the former criteria, 169 of the 203 sediments exceeded the published ERM, and using the second criteria, 142 sediments were 
above the PEC benchmark, which suggests that the Hg concentrations may have an adverse effect on aquatic organisms in the Mersey.

This survey has demonstrated that sedimentary hosted Hg concentrations remain elevated ( $\geq 2 \mathrm{mg} / \mathrm{kg}$ ) throughout much of the Mersey estuary and that $\mathrm{Hg}$ is associated with the organic matter. Surface sediments showed a spatial gradient from high $\mathrm{Hg}$ concentrations upstream and lower values in the outer estuary in line with distance from major chemical works and adjacent eroding salt marshes. The upper metre of salt marsh sediments was most contaminated with $\mathrm{Hg}(\sim 4 \mathrm{mg} / \mathrm{kg})$ and represents a potential threat to near surface dwelling aquatic organisms existing in these environments. A decrease in Hg content was observed at the surface of all four salt marsh cores indicating a possible recent decline in $\mathrm{Hg}$ contamination within the Mersey estuary since the 1980’s. A similar decline in near surface Hg concentrations from cores collected from within the main channel of the Mersey was not generally observed because of sedimentary mixing.

\section{Acknowledgements}

The authors thank the Environment Agency staff at the Northwest Regional Office for piloting the hovercraft (Sea-Spray) and the crew of the vessel Coastal Guardian for assistance in sample collection. The authors are indebted to Barbara Vickers for Hg analysis and all colleagues at British Geological Survey who were involved in the Mersey field campaign. This paper is published by permission of the Executive Director, British Geological Survey. 


\section{References}

Bengston, G. and Picado F. 2008. Mercury sorption to sediments: Dependence on grain size, dissolved organic carbon, and suspended bacteria. Chemosphere, 73, 526-531.

Boening, D. W., 2000. Ecological effects, transport, and fate of mercury: a general review. Chemosphere 40, 1335-1351.

Bryan, G. W., Langston, W. J., 1992. Bioavailability, accumulation and effects of heavy-metals in sediments with special reference to the United Kingdom estuaries- a review. Environ. Pollut. 76, 89-131.

Camacho-Ibar, V. F., Wrench, J. J., Head, P. C., 1992. Contrasting behaviour of arsenic and mercury in Liverpool Bay sediments. Est. Coast. Shelf Sci 34, 2336.

Clifton, R. J., Hamilton, E. I., 1982. The application of radioisotopes in the study of estuarine sedimentary processes. Est. Coast. Shelf Sci. 14, 433-446.

Craig, P. J., Moreton, P. A., 1986. Total mercury, methyl mercury and sulfide levels in British estuarine sediments .3. Water Res. 20, 1111-1118.

Fox, W. M., Johnson, M. S., Jones, S. R., Leah, R. T., Copplestone, D., 1999. The use of sediment cores from stable and developing salt marshes to reconstuct historical contamination profiles in the Mersey Estuary, UK. Mar. Environ. Res. 47, 311-329.

Haitzer, M., Aiken, G. R., Ryan, J. N., 2003. Binding of mercury (II) to aquatic humic substances:influence of pH and source of humic substances. Environ. Sci. Technol. 37, 2436-2441. 
Hamilton, E. I., Clarke, K. R., 1984. The recent sedimentation history of the esk estuary, Cumbria, UK - the application of radiochronology. Sci. Total Environ. 35, 325-386.

Harino, H., O'Hara, S. C. M., Burt, G. R., Chesman, B. S., Pope, N. D., Langston, W. J., 2003. Organotin compounds in Mersey and Thames estuaries a decade after UK TBT legislation. J. Mar. Biol. Assoc. U.K. 83, 11-22.

Harland, B. J., Taylor, D., Wither, A., 2000. The distribution of mercury and other trace metals in the sediments of the Mersey Estuary over 25 years 1974-1998. Sci. Total Environ. 253, 45-62.

Harland, B. J., Taylor, D., and Wither, A., 2001. Corrigendum to 'The distribution of mercury and other trace metals in the sediments of the Mersey Estuary over 25 years 1974-1998' Sci. Total Environ. 279, 231-231.

Kershaw, P. J., Pentreath, R. J., Woodhead, D. S., Hunt, G. J., 1992. A review of radioactivity in the Irish Sea: a report prepared for the marine pollution monitoring management group. MAFF directorate of fisheries research.

Langston, W. J., 1986. Metals in sediments and benthic organisms in the Mersey estuary. Est. Coast. Shelf Sci. 23, 239-261.

Leah, R. T., Johnson, M. S., Connor, L., Levene, C., 1997. Polychlorinated biphenyls in fish and shellfish from the Mersey Estuary and Liverpool Bay. Mar. Environ. Res. 43, 345-358.

Lee, S. V., Cundy, A. B., 2001. Heavy metal contamination and mixing processes in sediments from the Humber estuary, eastern England. Est. Coast. Shelf Sci. 53, 619-636. 
Long, E. R., MacDonald, D. D., Smith, S. L., Calder, F. D., 1995. Incidence of adverse biological effects within ranges of chemical concentrations in marine estuarine sediments. Environ. Manage. 19, 81-97.

MacDonald, D. D., Ingersol, C. G., Berger, T. A., 2000. Development and evaluation of consensus-based sediment quality guidelines for freshwater ecosystems. Arch. Environ. Contam. Toxicol. 39, 20-31.

Mackenzie, A. B., Scott, R. D., 1982. Radiocesium and plutonium in inter-tidal sediments from southern Scotland. Nature 299, 613-616.

Mackenzie, A. B., Scott, R. D., Allan, R. L., Benshaban, Y. A., Cook, G. T., Pulford, I. D., 1994. Sediment radionuclide profiles - implications for mechanisms of sellafield waste dispersal in the Irish Sea. J. Environ. Radioact. 23, 39-69.

NRA, 1995. The Mersey estuary: a report on environmental quality. National Rivers Authority Water Quality Series, 23, pp. 44.

Osborne, P. J., Preston, M. R., Chen, H.-Y., 1997. Azaarenes in sediments, suspended particles and aerosol associated with the River Mersey estuary. Mar. Chem. 58, 73-83.

Ritchie, J. C., McHenry, J. R., 1990. Application of radioactive fallout cesium-137 for measuring soil erosion and sediment accumulation rates and patterns: A review. J. Environ. Quality 19, 215-233.

Thomas, K. V., Balaam, J., Barnard, N., Dyer, R., Jones, C., Lavender, J., McHugh, M., 2002. Characterisation of potentially genotoxic compounds in sediments collected from United Kingdom estuaries. Chemosphere 49, 247-258.

Vane, C. H., Harrison, I., Kim, A. W., 2007. Polycyclic aromatic hydrocarbons (PAHs) and polychlorinated biphenyls (PCBs) in sediments from the Mersey Estuary, U.K. Sci.Total Environ. 374, 112-126. 
Vane, C.H., Harrison, I., Kim. A.W., Moss-Hayes, V., Vickers, B.P., Horton, B.P. 2008. Status of organic pollutants in surface sediments of Barnegat Bay-Little Egg Harbor Estuary, New Jersey, USA. Mar. Pollut. Bull. 56, 1802-1814.

Vane, C.H., Harrison, I., Kim, A.W., Moss-Hayes, V., Vickers, B.P. Hong, K. 2009. Organic and metal contamination in surface mangrove sediments of South China. Mar. Pollut. Bull. 58, 134-144.

Venkataraman, R., Bronson, F., Alrashkevich, V., Young, B. M., Field, M., 1999. Validation of in situ object counting system (ISOCS) mathematical efficiency calibration software. Nucl. Instrum. Methods Phys. Res., Sect. A. 422, 450454.

Venkataraman, R., Croft, S., Russ, W. R., 2005. Calculation of peak-to-total ratios for high purity germanium detectors using Monte-Carlo modeling. J. Radioanal. Nucl. Chem. 264, 183-191. 
Fig. 1. Location of sediment cores collected from the Mersey estuary, UK.

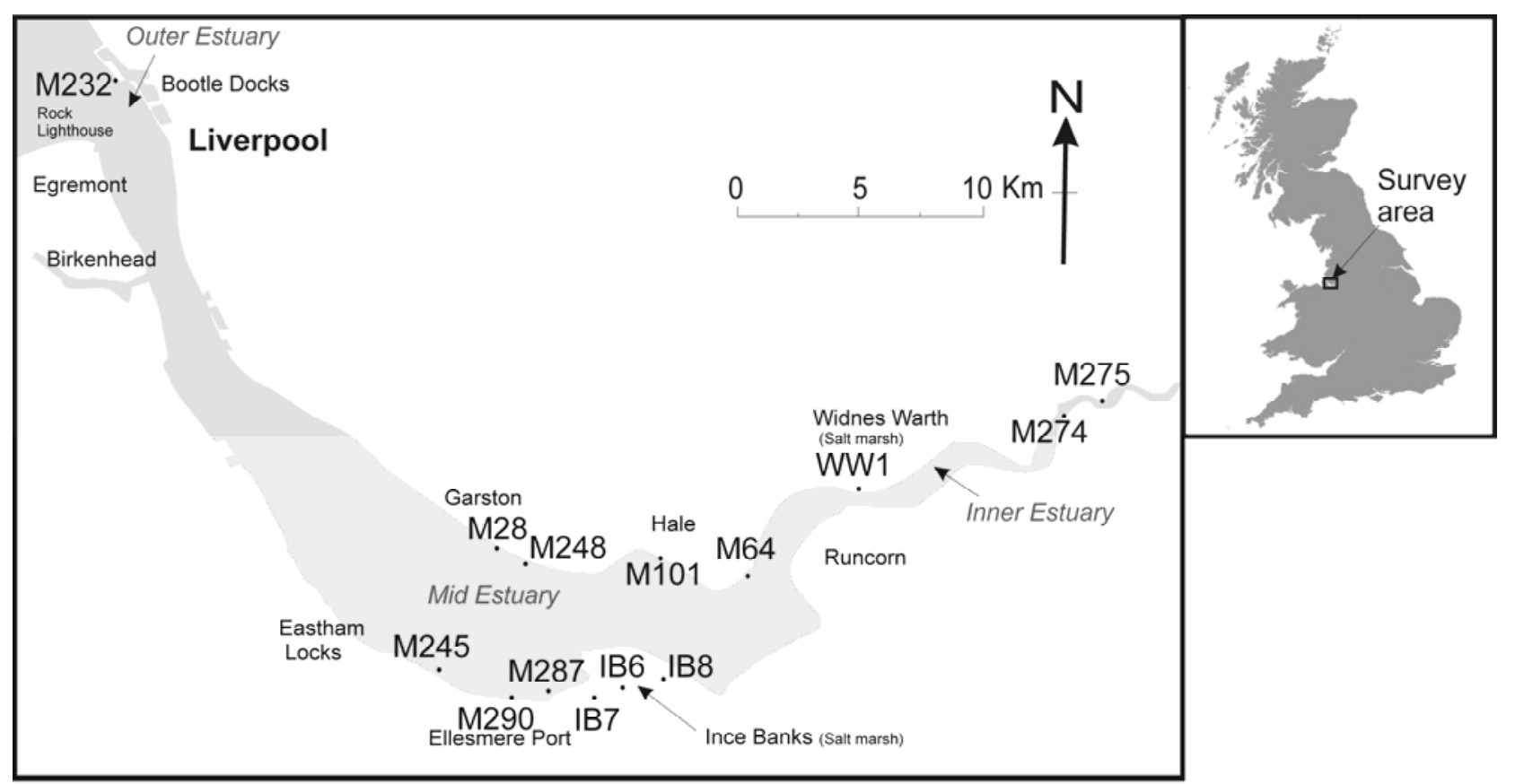


Fig. 2. Concentration of $\mathrm{Hg}(\mathrm{mg} / \mathrm{kg}$ dry wt.) in surface sediments $(0-10 \mathrm{~cm})$ of the Mersey Estuary, UK.

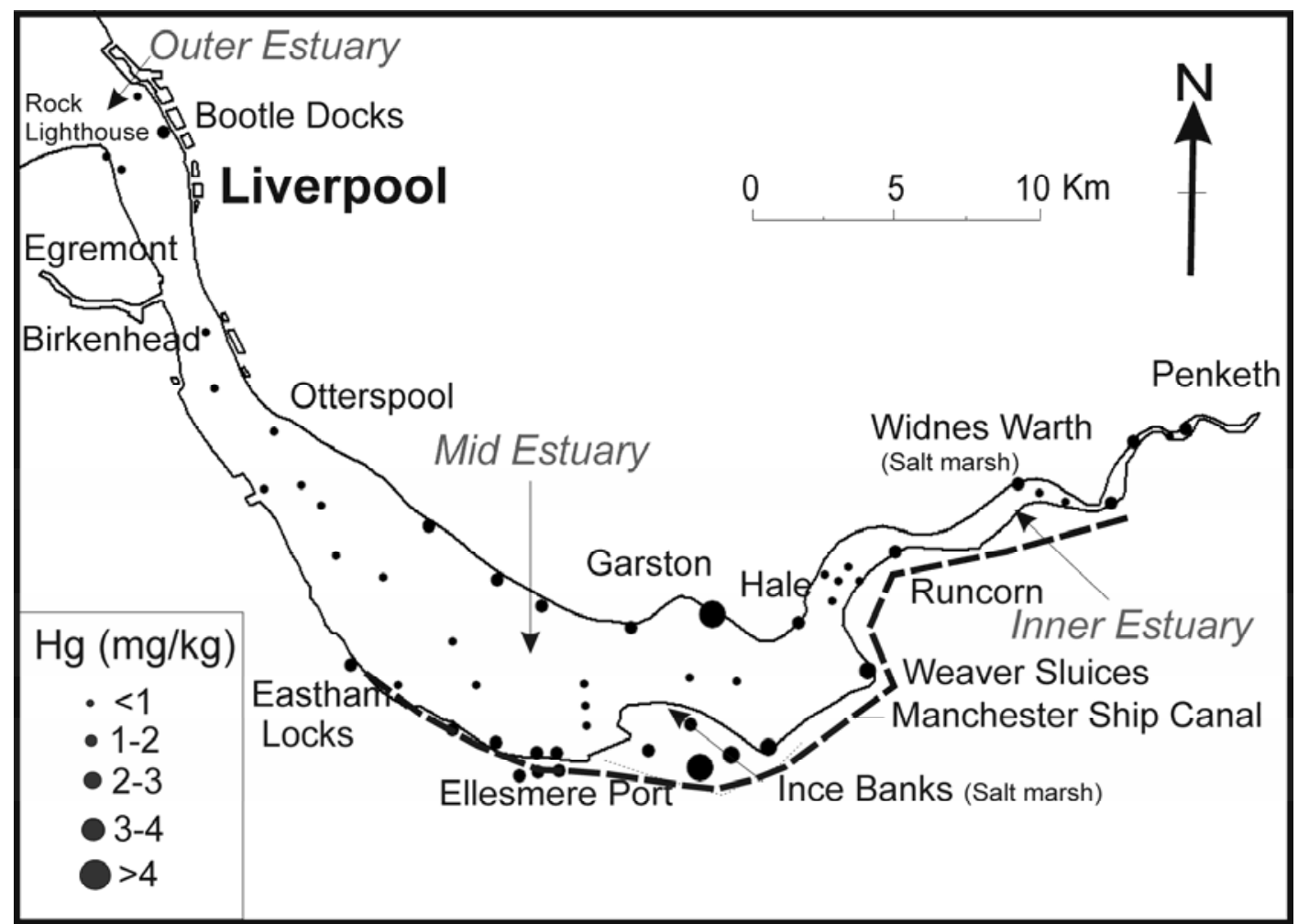


Fig. 3. Total Hg concentration (mg/kg dry wt.) versus Loss on Ignition (LoI) with sediment depth. Core locations are presented in Fig. 1.

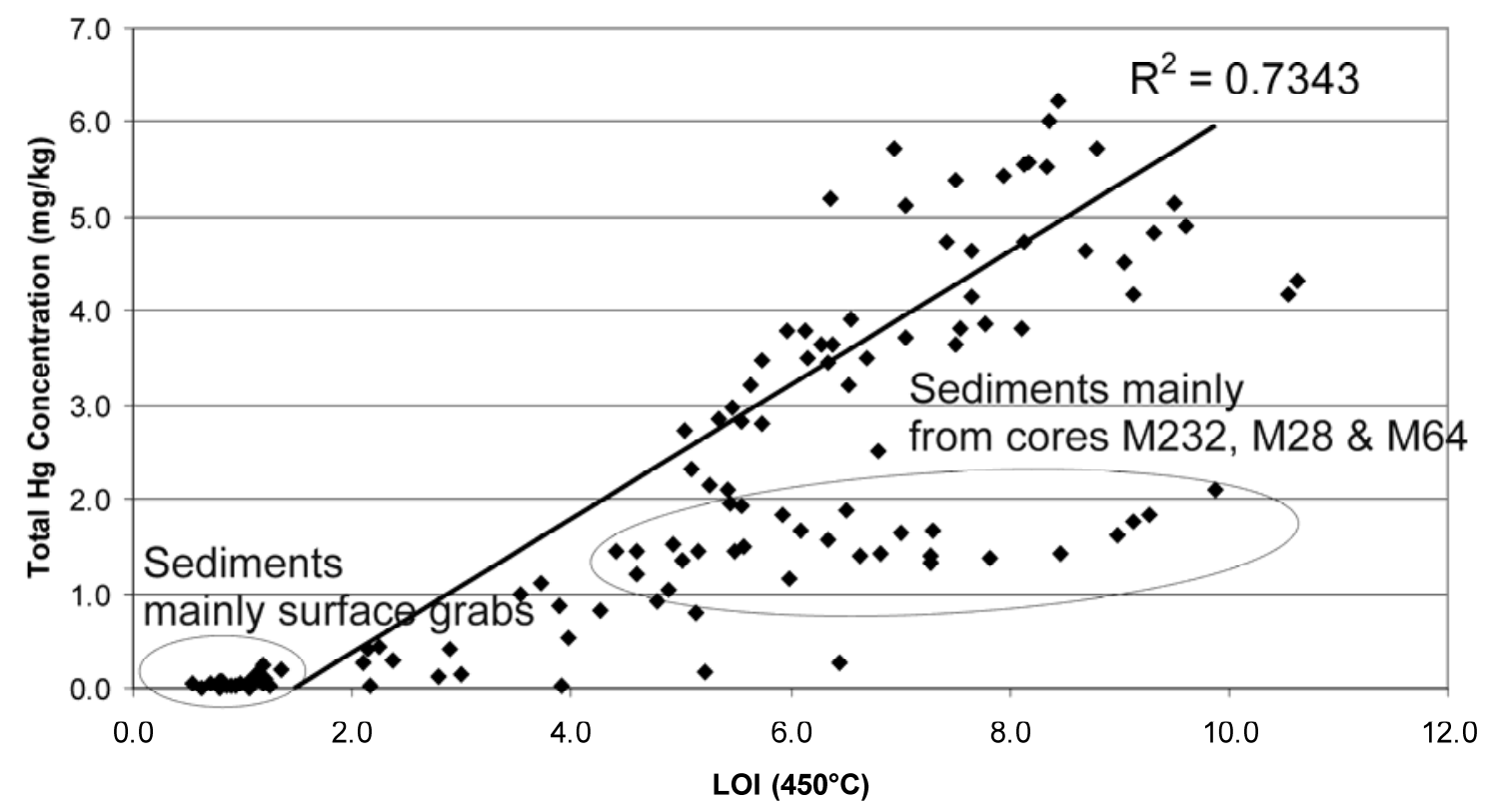


Fig. 4. Variation in total Hg concentrations (mg/kg dry wt) and Loss on Ignition (LoI) with depth. Sediment core locations are presented in F.1.

$x$ 
Fig. 5. Variation in ${ }^{137}$ Cs activity with sediment depth at Ellesmere Port (M290) and M287. Note that the decline in activity in the upper and lower 8-10 $\mathrm{cm}$ of each sediment core is an artefact of the automated core logger method employed.

M290

\section{Activity (Bq/kg)}

0 50100150200250300350400450500

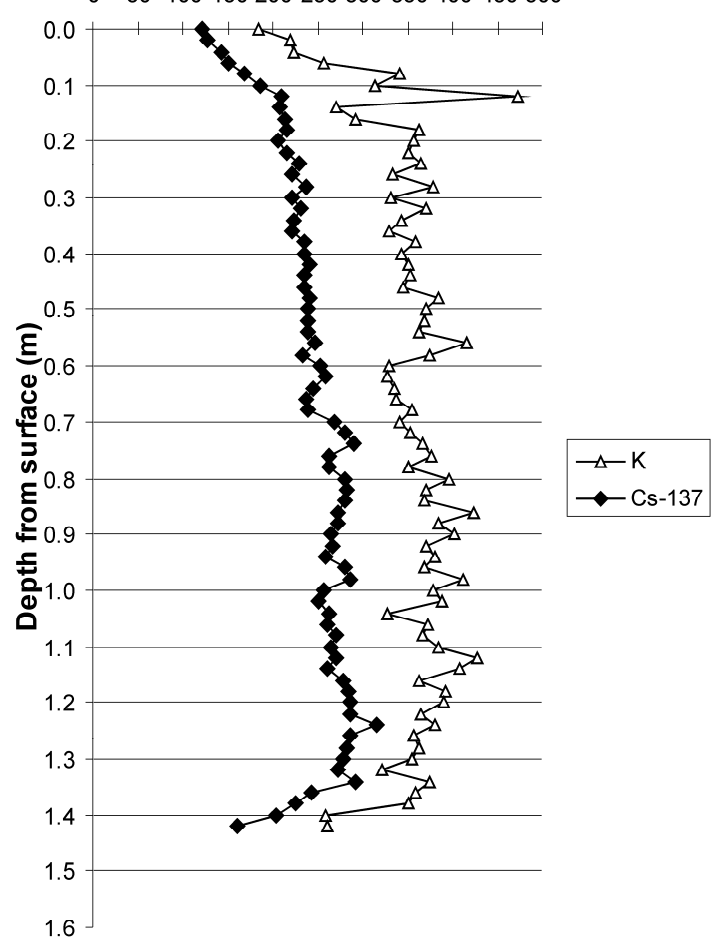

M286

Activity (Bq/kg)

50100150200250300350400450500

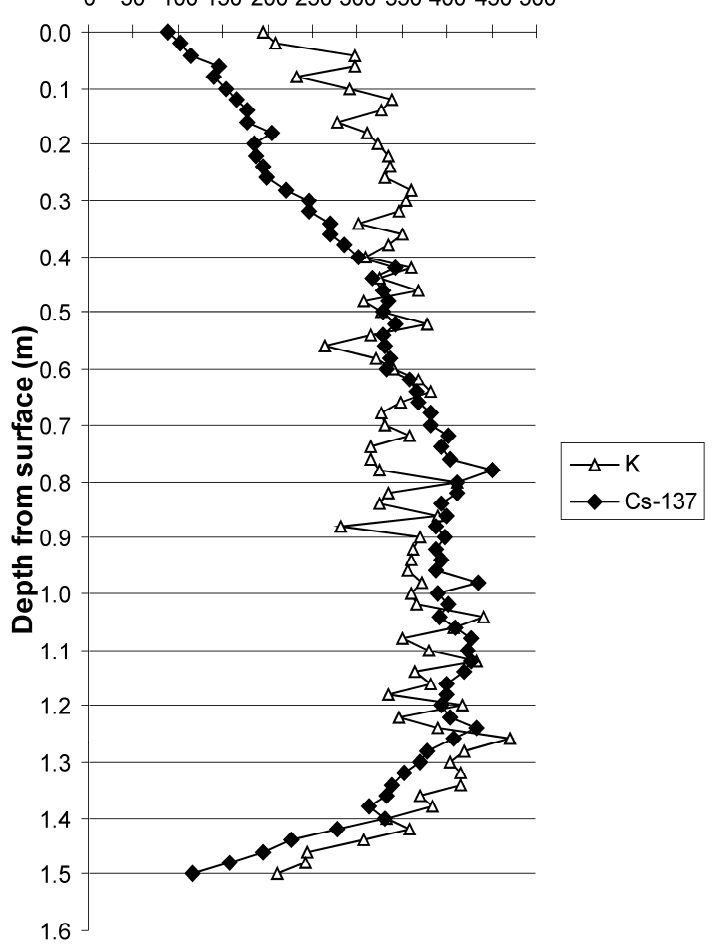


Fig. 6. Variation in total Hg concentrations (mg/kg dry wt) and Loss on Ignition (LoI) with depth for salt marsh cores collected from Ince Banks (IB) and Widnes Warth (WW). Core locations are presented in Fig. 1.

IB7

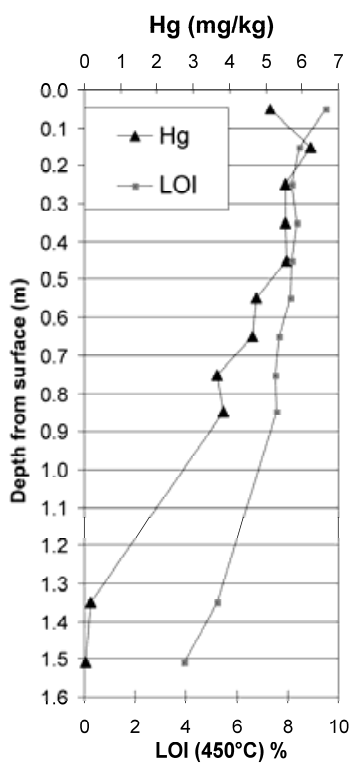

IB6

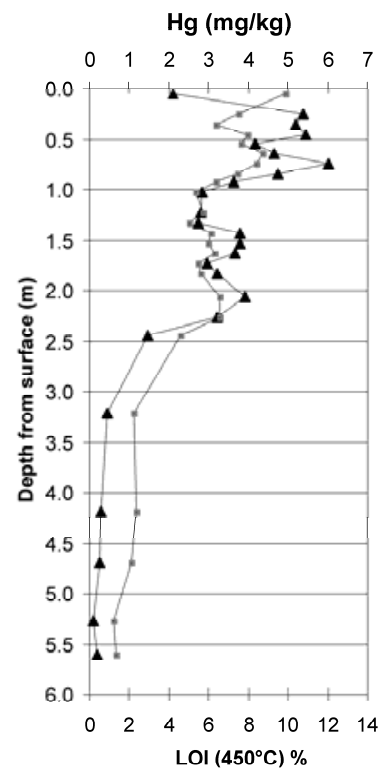

IB8

$\mathrm{Hg}(\mathrm{mg} / \mathrm{kg})$

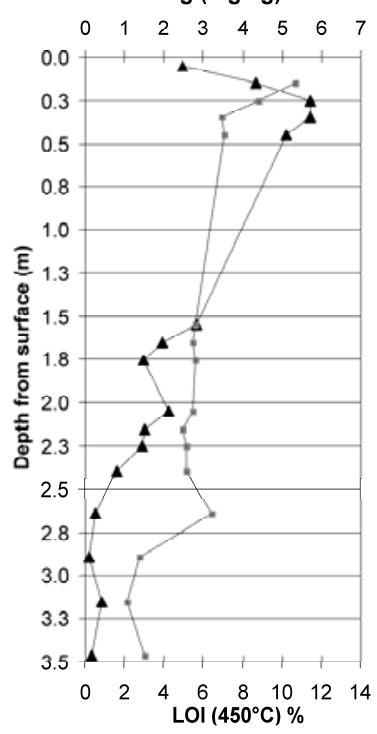

WW1

$\mathrm{Hg}(\mathrm{mg} / \mathrm{kg})$

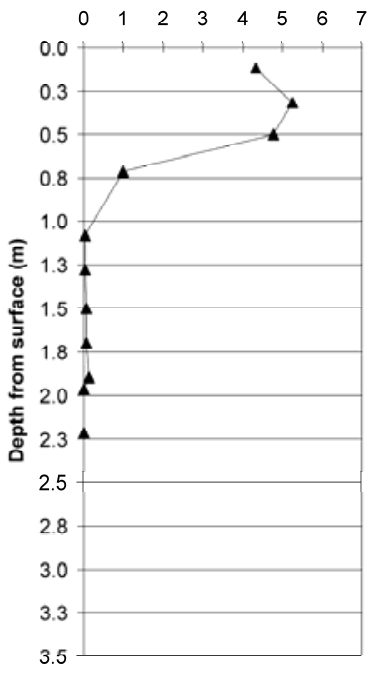


Table 1. Quality control values measured in marine sediment certified reference materials.

\begin{tabular}{ll|ll}
\hline Certified Marine Reference Material & $\mathrm{Hg}(\mathrm{mg} / \mathrm{kg})$ & Certified Marine Reference Material & $\mathrm{Hg}(\mathrm{mg} / \mathrm{kg})$ \\
\hline BEST-1 & $0.092( \pm 0.009)$ & PACS-1 & $4.57( \pm 0.16)$ \\
Permissible Max. & 0.1018 & Permissible Max. & 4.9255 \\
Permissible Min. & 0.0794 & Permissible Min. & 4.0221 \\
QC Run 1 & 0.089 & QC Run 6 & 4.342 \\
QC Run 2 & 0.089 & QC Run 7 & 4.268 \\
QC Run 3 & 0.090 & QC Run 8 & 4.588 \\
QC Run 4 & 0.089 & QC Run 9 & 4.422 \\
QC Run 5 & 0.085 & & \\
\hline
\end{tabular}

